\title{
Supplementation of copaiba or sucupira oils in broiler diets
}

\author{
Suplementação de óleo de copaíba ou sucupira na ração de frangos de corte
}

\author{
NOLETO, Raiana Almeida ${ }^{1 *}$; LEANDRO, Nadja Susana Mogyca ${ }^{1}$; MELLO, Heloisa \\ Helena de Carvalho ${ }^{1}$; CONCEIÇÃO, Edemilson Cardoso da ${ }^{2}$; ARAÚJO, Itallo Conrado \\ Sousa de ${ }^{3}$; OLIVEIRA, Eduardo Miranda de ${ }^{1}$; PAZ, Paulo Henrique Sousa da ${ }^{1}$; \\ BARBOSA, Aleane Francisca Cordeiro ${ }^{4}$
}

\author{
${ }^{1}$ Universidade Federal de Goiás, Escola de Veterinária e Zootecnia, Departamento de Zootecnia, Goiânia, \\ Goiás, Brasil. \\ ${ }^{2}$ Universidade Federal de Goiás, Faculdade de Farmácia, Goiânia, Goiás, Brasil. \\ ${ }^{3}$ Universidade Federal de Minas Gerais, Escola de Veterinária, Departamentos de Zootecnia, Belo \\ Horizonte, Minas Gerais, Brasil. \\ ${ }^{4}$ Universidade Federal do Tocantins, Escola de Medicina Veterinária e Zootecnia, Departamento de \\ Produção Animal, Araguaína, Tocantins. \\ *Endereço para correspondência: raianazoo@hotmail.com
}

\section{SUMMARY}

The aim of this study was to evaluate the effect of supplemental copaiba or sucupira oils on broiler performance and intestinal health. A total of 600 one-day old Cobb 500 male broilers were distributed in a completely randomized design with four treatments and six replicates with 25 broilers each. To increase the health challenge, the broilers were reared on reused litter. The treatments consisted of: control diet; diet with a performance enhancing antibiotic (avilamycin); diet with $2,000 \mathrm{mg} / \mathrm{kg}$ copaiba oil and a diet with $500 \mathrm{mg} / \mathrm{kg}$ sucupira oil. Data were submitted to analysis of variance and Tukey test $(5 \%)$. The addition of sucupira oil at $500 \mathrm{mg} / \mathrm{kg}$ decreased broiler performance at 21 , 33 , and 40 days of age, whereas the addition of copaiba oil resulted in similar performance relative to the antibiotic. Dietary supplementation of copaiba or sucupira oils did not change the intestinal epithelium of broilers. The addition of sucupira oil negatively affected broiler performance. Copaiba oil can be used in broiler diets as a performance enhancer.

Keywords: antimicrobials, Copaifera langsdorfii, Pterodon emarginatus

\section{RESUMO}

Objetivou-se avaliar a utilização de óleo de copaíba ou sucupira na ração de frangos de corte, sobre o desempenho e saúde intestinal. Foram utilizados 600 pintos de corte machos, da linhagem Cobb500 com um dia de idade, distribuídos em delineamento inteiramente casualizado, com quatro tratamentos e seis repetições com 25 aves cada. Com o objetivo de aumentar o desafio, as aves foram criadas sobre cama reutilizada. Os tratamentos consistiram de: ração controle; ração com antibiótico melhorador de desempenho avilamicina; ração com $2.000 \mathrm{mg} / \mathrm{kg}$ de óleo de copaíba e ração com $500 \mathrm{mg} / \mathrm{kg}$ de óleo sucupira. Os dados foram submetidos à análise de variância e teste Tukey (5\%). A adição de $500 \mathrm{mg} / \mathrm{kg}$ do óleo de sucupira resultou em queda do desempenho das aves no período de 21, 33 e 40 dias de idade, já a adição do óleo de copaíba proporcionou resultados de desempenho semelhantes ao antibiótico. A suplementação com óleo de copaíba ou sucupira não promoveu alterações no epitélio intestinal dos frangos avaliados. A adição do óleo de sucupira foi prejudicial ao desempenho das aves. O óleo de copaíba pode ser utilizado em dietas para frangos como melhorador de desempenho.

Palavras-chave: antimicrobianos, Copaifera langsdorfii, Pterodon emarginatus 


\section{INTRODUCTION}

The performance enhancing antibiotics (PEA) are widely used in poultry production to improve productivity and animal health status. However, its use has been questioned due to the possible selection of resistant bacterial strains, resulting in the restriction and/or prohibition of these additives (FUKAYAMA et al., 2005). Then, research seeking alternative products capable to replace traditional PEAs with the same efficiency has been intensified. The phytogenic additives such as extracts and oils (AMAD et al., 2011) are among the possible alternatives, being defined as substances derived from plants rich in bioactive molecules, with a wide range of physiological effects (BURT, 2004).

The benefits of phytogenic additives as animal performance enhancers are related to the modification of the intestinal microbiota through a reduction of pathogenic microbial load (HASHEMI \& DAVOODI, 2011), and an increase in nutrient digestibility by stimulating the secretion of digestive enzymes (BENMAHDI et al., 2010).

Copaiba (Copaifera sp.) and sucupira (Pterodon sp.), plants from the Brazilian cerrado, have bioactive compounds such as terpenes (monoterpenes and sesquiterpenes), flavonoids and alkaloids, specially sesquiterpene $\beta$-caryophyllene (LEANDRO et al., 2010; DUTRA et al., 2012; BEZERRA et al., 2010), as well as anti-inflammatory, anti-scarring, and antimicrobial properties (MONTES et al., 2009; SANTOS et al., 2010) and leishmanicidal activity (DUTRA et al., 2009).

Copaiba oil showed positive responses against bacteria such as Escherichia coli and Staphylococcus aureus (MENDONÇA \& ONOFRE, 2009; PIERI et al., 2012), whereas the oil from the sucupira seed was effective against strains of Staphylococcus aureus (SANTOS et al., 2010; DUTRA et al., 2009). $\beta$-caryophyllene can be considered the main compound responsible for the antimicrobial activity of these oils (LEANDRO et al., 2010).

Considering that copaiba as well as sucupira are plants with antimicrobial properties, little studied in vivo and with potential to be used in animal production, the aim was to evaluate the effect of supplemental copaiba or sucupira oils on broiler performance and intestinal histomorphometry.

\section{MATERIAL AND METHODS}

This study was approved by the Ethics Committee on Animal Use of the Federal University of Goiás (UFG; under the protocol number 082/12) and conducted at the Poultry Study Center of the Veterinary and Animal Science School (UFG).

A total of 600 one-day old Cobb 500 male broilers were used. The broilers were housed in boxes of $5.25 \mathrm{~m}^{2}$, individually supplied with tubular feeders and pendulum drinkers. To increase the sanitary challenge, the broilers were reared on rice straw as litter substrate previously used by a broiler flock through a complete cycle (1 to 42 days).

A completely randomized design with four treatments and six replicates with 25 broilers each was used. The treatments consisted of: control diet (no additives); control diet with a performance enhancing antibiotic (avilamycin); control diet with $2,000 \mathrm{mg} / \mathrm{kg}$ copaiba oil and a control diet with $500 \mathrm{mg} / \mathrm{kg}$ sucupira oil. The levels of oils used were determined based on previous trials performed at UFG with the dietary supplementation of copaiba or sucupira oils in broilers. The 
levels that resulted in the best performance (unpublished data) were used in the present study. Copaiba oil was purchased from a commercial establishment and the sucupira seeds were purchased from a cooperative. Copaiba oil was extracted directly from the stem of copaiba tree, and sucupira oil was obtained by cold compression of seeds conducted by the Laboratory of Research in Natural Products of the Faculty of Pharmacy of the Federal University of Goiás. The content of $\beta$-caryophyllene in both oils was measured by a highperformance liquid chromatography method, with levels of $213.1 \mathrm{mg} / \mathrm{mL}$ in copaiba oil and 1,387 mg/mL in sucupira oil.

The control diets (Table 1) were isonutritive and formulated according to the recommendations of Rostagno et al. (2011). The inclusion of avilamycin, copaiba oil and sucupira oil was done in substitution of starch. For that, the amount of antibiotic and oils added to the feed was subtracted from the starch. To incorporate the oils into the feed, they were first added to the soybean oil and then, after homogenate, were added to the other ingredients in the mixer. Broilers received feed and water ad libitum, and mortality was recorded daily during the experimental period.

Table 1. Composition and calculated nutritional value of the control $\operatorname{diet}^{1}$

\begin{tabular}{|c|c|c|c|c|}
\hline \multirow{2}{*}{ Ingredients (\%) } & \multicolumn{4}{|c|}{ Phases (ages in days) } \\
\hline & 1 to 7 & 8 to 21 & 22 to 33 & 34 to 40 \\
\hline Corn grain & 54.93 & 59.06 & 61.67 & 66.29 \\
\hline Soybean meal 45\% & 38.26 & 34.77 & 31.56 & 27.36 \\
\hline Soybean oil & 2.24 & 2.21 & 3.20 & 3.06 \\
\hline Dicalcium phosphate & 1.91 & 1.51 & 1.27 & 1.07 \\
\hline Limestone & 0.89 & 0.91 & 0.85 & 0.76 \\
\hline Salt & 0.49 & 0.47 & 0.44 & 0.44 \\
\hline DL-Methionine & 0.36 & 0.29 & 0.26 & 0.24 \\
\hline L-Lysine HCL & 0.29 & 0.22 & 0.19 & 0.23 \\
\hline L-Threonine & 0.11 & 0.06 & 0.04 & 0.05 \\
\hline Vitamin Supplement $^{1}$ & 0.10 & 0.10 & 0.10 & 0.10 \\
\hline Mineral Supplement ${ }^{2}$ & 0.05 & 0.05 & 0.05 & 0.05 \\
\hline Anticoccidial & 0.05 & 0.05 & 0.05 & 0.05 \\
\hline Starch & 0.30 & 0.30 & 0.30 & 0.30 \\
\hline Total (\%) & 100.0 & 100.0 & 100.0 & 100.0 \\
\hline Metabolizable Energy (kcal/kg) & 2,950 & 3,000 & 3,100 & 3,150 \\
\hline Protein $(\%)$ & 22.2 & 20.8 & 19.5 & 18.0 \\
\hline Calcium $(\%)$ & 0.92 & 0.81 & 0.73 & 0.63 \\
\hline Available phosphorus (\%) & 0.47 & 0.39 & 0.34 & 0.29 \\
\hline Digestible lysine (\%) & 1.31 & 1.17 & 1.08 & 1.01 \\
\hline Digestible methionine + cystine $(\%)$ & 0.94 & 0.85 & 0.79 & 0.74 \\
\hline Digestible methionine (\%) & 0.65 & 0.56 & 0.51 & 0.47 \\
\hline Digestible threonine (\%) & 0.85 & 0.76 & 0.70 & 0.66 \\
\hline Digestible tryptophan (\%) & 0.25 & 0.24 & 0.22 & 0.19 \\
\hline Sodium $(\%)$ & 0.22 & 0.21 & 0.20 & 0.19 \\
\hline
\end{tabular}

${ }^{1}$ Guarantee levels per kilogram of product: Vitamin A 3,125 IU, Vitamin D3 550,000 IU, Vitamin E $3,750 \mathrm{mg}$, Vitamin K3 $625 \mathrm{mg}$, Vitamin B12 $250 \mathrm{mg}$, Vitamin B2 1,125 mg, Vitamin B6 $250 \mathrm{mg}$, Vitamin B12 3,750 mg, Niacin 9,500 mg, Calcium Pantothenate 3,750 mg, Folic Acid $125 \mathrm{mg}$, DLMethionine 350,000 mg, Choline Chloride 50\% 150,000 mg, Selenium $50 \mathrm{mg}$, Antioxidant 2,500 mg, Excipient q.s.p. 1,000 g. ${ }^{2}$ Mineral Supplement - Guarantee levels: Manganese 150,000 mg, Zinc 100,000 $\mathrm{mg}$, Iron 100,000 mg, Copper 16,000 mg, Iodine 1,500 mg. 
At 7, 21, 33 and 40 days of age, the leftovers of feed and the broilers were weighed to determine the average weight, obtained by dividing the total broilers weight of the plot by the number of birds in the plot; the weight gain, obtained by the difference between the average weight and the initial broiler weight, divided by the number of birds; the feed intake, obtained by the difference between the amount of feed supplied and the leftovers over a week; the feed conversion, calculated by the relationship between feed intake and weight gain, corrected for the total weight of dead birds; and viability, obtained by subtracting $100 \%$ from the mortality value. The productive efficiency index (PEI) was calculated according to the formula PEI $=$ weight gain $(\mathrm{kg}) \mathrm{x}$ viability (\%) / feed conversion $(\mathrm{kg} / \mathrm{kg}) \quad \mathrm{x}$ slaughter age (days).

At 40 days of age, all broilers of each plot were weighed; subsequently, one broiler from each experimental unit, representing the average weight of the plot, was slaughtered by cervical dislocation after four hours of fasting. The small intestine was then removed. Segments of approximately $2.0 \mathrm{~cm}$ of the duodenum, jejunum and ileum were collected and fixed in $10 \%$ buffered formaldehyde solution for 24 hours. After fixation, the samples were stored in $70 \%$ alcohol and processed according to the methodology described by LUNA (1968) and stained by the Hematoxylin Eosin (HE) method. After staining, fivefold magnification images were obtained with the aid of the Leica DM 4000B optical microscope coupled to a microcomputer. The images were analyzed with the aid of ImageJ software, in which 30 measurements of villus height and crypt depth of each small intestine portion were performed per repetition.

Statistical analysis was performed through the GLM procedure of SAS software (SAS INSTITUTE, 2009). The data were submitted to analysis of variance (ANOVA) and the averages were compared by the Tukey's test at $5 \%$ significance.

\section{RESULTS AND DISCUSSION}

Broiler performance was not influenced $(\mathrm{P}>0.05)$ by treatments from 1 to 7 days of age (Table 2). The reused litter was not enough to challenge the broilers, situation in which there would be benefits of using antibiotics in the feed. According to UTIYAMA et al. (2006), a sufficient health challenge is needed, so that the performance enhancing additives may provide better results. Possibly, the pathogenic microbial load of the poultry litter used was not high enough to interfere with the broiler performance.

BARRETO et al. (2008) also found no change in performance when broilers were fed diets with antibiotic (avilamycin) or a mixture of vegetable extract composed of essential oil of cinnamon, clove, oregano, and red pepper at the starter phase. The authors attributed this result to the absence of microbiological challenge or inactivity of added substances or levels.

Conversely, KOIYAMA et al. (2013) verified that the addition of $200 \mathrm{mg} / \mathrm{kg}$ copaiba oil in broiler pre-starter diet resulted in a weight gain lower than the antibiotic group (virginiamycin).

From 1 to 21 days of age, the use of sucupira oil resulted in lower weight gain and average weight in relation to the other treatments, resulting in worse feed conversion compared to the control 
group $(\mathrm{P}<0.05)$ (Table 3). The lower feed intake of broilers fed sucupira oil may have been associated to the reduced weight gain and lower final weight observed. The astringent effect of sucupira oil may have negatively interfered with the palatability of the diet, since, according to FREITAS et al. (2012), feed palatability is one of the factors that influence the amount of feed consumed voluntarily.

Table 2. Initial weight (IW), feed intake (FI), weight gain (WG), average weight (AW7), feed conversion (FC), and viability (V) of broilers from 1 to 7 days fed diets supplemented with copaiba or sucupira oils

\begin{tabular}{lcccccc}
\hline Treatments & IW $(\mathrm{g})$ & FI $(\mathrm{g})$ & WG $(\mathrm{g})$ & AW7 $(\mathrm{g})$ & FC $(\mathrm{g} / \mathrm{g})$ & $\mathrm{V}(\%)$ \\
\hline Control & 48.2 & 160.0 & 149.6 & 197.8 & 1.073 & 99.3 \\
Avilamycin & 48.4 & 168.2 & 152.5 & 200.9 & 1.103 & 100.0 \\
Copaiba & 48.3 & 168.2 & 147.5 & 195.8 & 1.144 & 99.3 \\
Sucupira & 48.2 & 157.1 & 143.9 & 192.1 & 1.094 & 100.0 \\
\hline P value & 0.904 & 0.051 & 0.149 & 0.146 & 0.172 & 0.619 \\
CV $(\%)$ & 0.83 & 4.66 & 4.07 & 3.10 & 4.85 & 1.18 \\
\hline
\end{tabular}

Table 3. Feed intake (FI), weight gain (WG), average weight (AW21), feed conversion (FC), and viability (V) of broilers from 1 to 21 days fed diets supplemented with copaiba or sucupira oils

\begin{tabular}{lccccc}
\hline Treatments & FI $(\mathrm{g})$ & WG $(\mathrm{g})$ & AW21 $(\mathrm{g})$ & $\mathrm{FC}(\mathrm{g} / \mathrm{g})$ & $\mathrm{V}(\%)$ \\
\hline Control & $1253.8^{\mathrm{ab}}$ & $835.9^{\mathrm{a}}$ & $884.1^{\mathrm{a}}$ & $1.512^{\mathrm{b}}$ & 97.3 \\
Avilamycin & $1267.1^{\mathrm{ab}}$ & $821.5^{\mathrm{a}}$ & $869.9^{\mathrm{a}}$ & $1.553^{\mathrm{ab}}$ & 97.6 \\
Copaiba & $1269.3^{\mathrm{a}}$ & $830.8^{\mathrm{a}}$ & $879.1^{\mathrm{a}}$ & $1.543^{\mathrm{ab}}$ & 98.0 \\
Sucupira & $1192.6^{\mathrm{b}}$ & $733.3^{\mathrm{b}}$ & $781.6^{\mathrm{b}}$ & $1.633^{\mathrm{a}}$ & 98.7 \\
\hline P value & 0.024 & 0.0001 & 0.0001 & 0.011 & 0.859 \\
CV $(\%)$ & 3.53 & 4.20 & 3.96 & 3.67 & 2.86 \\
\hline
\end{tabular}

Means followed by lowercase letters in column differ by Tukey's test $(\mathrm{P}<0.05)$.

Broilers fed copaiba oil had a similar feed intake, weight gain, average weight, and feed conversion to that of control broilers and the group receiving avilamycin (antibiotic). Different from that observed in the present study, AGUILAR et al. (2013) found that the body weight of broilers fed copaiba essential oil above $0.15 \mathrm{~mL} / \mathrm{kg}(0.30$, 0.45 and $0.60 \mathrm{~mL} / \mathrm{kg}$ ) was lower than that of birds supplemented with the antibiotic (virginiamycin), from 1 to 21 days of age. The authors attributed this result to a possible toxicity caused by copaiba essential oil in young birds, which negatively affected their growth. Considering the evaluation period from 1 to 33 days of age (Table 4), the addition of sucupira oil interfered negatively with broiler performance $(\mathrm{P}<0.05)$. The weight gain and average weight were lower in broilers supplemented with sucupira oil when compared to the other treatments. Feed intake was lower in relation to the control group and to the group that received the copaiba oil in the diet. 
Table 4. Feed intake (FI), weight gain (WG), average weight (AW33), feed conversion (FC), and viability (V) of broilers from 1 to 33 days fed diets supplemented with copaiba or sucupira oils

\begin{tabular}{lccccc}
\hline Treatments & FI $(\mathrm{g})$ & WG $(\mathrm{g})$ & AW33 $(\mathrm{g})$ & FC $(\mathrm{g} / \mathrm{g})$ & $\mathrm{V}(\%)$ \\
\hline Control & $2985.5^{\mathrm{a}}$ & $1770.9^{\mathrm{a}}$ & $1819.2^{\mathrm{a}}$ & 1.697 & 97.3 \\
Avilamycin & $2933.5^{\mathrm{ab}}$ & $1738.5^{\mathrm{a}}$ & $1786.9^{\mathrm{a}}$ & 1.706 & 96.8 \\
Copaiba & $3002.3^{\mathrm{a}}$ & $1800.6^{\mathrm{a}}$ & $1848.9^{\mathrm{a}}$ & 1.687 & 97.3 \\
Sucupira & $2761.7^{\mathrm{b}}$ & $1623.2^{\mathrm{b}}$ & $1671.4^{\mathrm{b}}$ & 1.716 & 96.7 \\
\hline P value & 0.003 & $<0.0001$ & $<0.0001$ & 0.770 & 0.980 \\
CV $(\%)$ & 3.65 & 2.78 & 2.70 & 2.99 & 3.57 \\
\hline
\end{tabular}

Means followed by lowercase letters in column differ by Tukey's test $(\mathrm{P}<0.05)$.

Although broilers have a reduced number of taste buds and, therefore, a poorly developed palate (El BOUSHY \& KENNEDY, 1987), the lower feed intake when sucupira oil was added may be related to feed palatability, which consequently impaired the performance. The addition of copaiba oil in broiler diets resulted in similar performance to the control or antibiotic groups. According to WINDISCH et al. (2008), there is great variation in biological effects from the use of natural products, so some aspects such as plant species, active principle and inclusion level are essential and should be considered. BARRETO et al. (2008) emphasized that the inclusion level is one of the factors influencing the site and mode of action of the active principles of natural additives.

From 1 to 40 days of age, the addition of sucupira oil in the diet resulted in lower feed intake compared to the control group and the group receiving copaiba oil $(\mathrm{P}<0.05)$ (Table 5). Broilers fed sucupira oil, both during the starter and grower phase, continued to have worse results for weight gain and average weight in relation to the control group $(\mathrm{P}<0.05)$. The lower feed intake may be responsible for the reduced weight gain and average weight, and this level of sucupira oil seems not to have been appropriate; lower levels should be evaluated for a better understanding of the response of this additive on broiler performance.

Table 5. Feed intake (FI), weight gain (WG), average weight (AW40), feed conversion (FC), viability (V), and productive efficiency index (PEI) of broilers from 1 to 40 days fed diets supplemented with copaiba or sucupira oils

\begin{tabular}{lcccccc}
\hline Treatments & FI $(\mathrm{g})$ & WG $(\mathrm{g})$ & AW40 $(\mathrm{g})$ & FC $(\mathrm{g} / \mathrm{g})$ & $\mathrm{V}(\%)$ & PEI \\
\hline Control & $4040.0^{\mathrm{a}}$ & $2255.8^{\mathrm{a}}$ & $2304.1^{\mathrm{a}}$ & 1.829 & 94.7 & 287.4 \\
Avilamycin & $3969.6^{\mathrm{ab}}$ & $2185.3^{\mathrm{ab}}$ & $2233.7^{\mathrm{ab}}$ & 1.847 & 96.0 & 281.5 \\
Copaiba & $4004.4^{\mathrm{a}}$ & $2205.4^{\mathrm{ab}}$ & $2253.7^{\mathrm{ab}}$ & 1.858 & 93.3 & 267.1 \\
Sucupira & $3767.1^{\mathrm{b}}$ & $2074.7^{\mathrm{b}}$ & $2122.9^{\mathrm{b}}$ & 1.838 & 96.0 & 266.3 \\
\hline P value & 0.013 & 0.027 & 0.027 & 0.804 & 0.691 & 0.111 \\
CV $(\%)$ & 3.51 & 4.39 & 4.30 & 2.93 & 4.61 & 6.12 \\
\hline
\end{tabular}

Means followed by lowercase letters in column differ by Tukey's test $(\mathrm{P}<0.05)$. 
In relation to copaiba oil, the level studied $(2,000 \mathrm{mg} / \mathrm{kg})$ did not influence $(\mathrm{P}>0.05)$ the performance in the total period. Nevertheless, AGUILAR et al. (2013), when evaluating increasing levels $(0.15,0.30,0.45$ or $0.60 \mathrm{~mL} / \mathrm{kg})$ of copaiba essential oil in broiler diets, verified that the highest level resulted in birds with lower body weight compared to the antibiotic group (virginiamycin) in the total rearing period. The productive efficiency index (PEI) was not influenced by the treatments $(\mathrm{P}>0.05)$. The PEI is an indication whether the rearing system is being efficient or not and it is used by many companies as a basis for farmer's remuneration.

There were no significant differences between treatments for villus height, crypt depth and villus/crypt ratio of the duodenum, jejunum and ileum at 40 days of age (Table 6). According to KUZMUK et al. (2005), the villus height and crypt depth are considered indicators of a good intestinal development. Under normal conditions, the villus/crypt ratio is high.

Table 6. Villus height (Villus), crypt depth (Crypt) and villus/crypt ratio (V/C) of the duodenum, jejunum and ileum of broilers from 1 to 40 days fed diets supplemented with copaiba or sucupira oils

\begin{tabular}{lccccccccc}
\hline \multirow{3}{*}{ Treatments } & \multicolumn{3}{c}{ Duodenum } & \multicolumn{3}{c}{ Jejunum } & \multicolumn{3}{c}{ Ileum } \\
\cline { 2 - 10 } & $\begin{array}{c}\text { Villus } \\
(\mu \mathrm{m})\end{array}$ & $\begin{array}{c}\text { Crypt } \\
(\mu \mathrm{m})\end{array}$ & V/C & $\begin{array}{c}\text { Villus } \\
(\mu \mathrm{m})\end{array}$ & $\begin{array}{c}\text { Crypt } \\
(\mu \mathrm{m})\end{array}$ & V/C & $\begin{array}{c}\text { Villus } \\
(\mu \mathrm{m})\end{array}$ & $\begin{array}{c}\text { Crypt } \\
(\mu \mathrm{m})\end{array}$ & V/C \\
\hline Control & 1,255 & 356.9 & 3.62 & 883.5 & 284.7 & 3.26 & 693.0 & 222.8 & 3.22 \\
Avilamycin & 1,346 & 412.0 & 3.31 & 740.8 & 318.1 & 2.47 & 685.5 & 271.7 & 2.59 \\
Copaiba & 1,173 & 422.2 & 2.86 & 829.8 & 348.2 & 2.41 & 537.1 & 243.4 & 2.23 \\
Sucupira & 1,354 & 438.2 & 3.18 & 847.9 & 290.9 & 2.93 & 622.8 & 236.1 & 2.66 \\
\hline P value & 0.146 & 0.145 & 0.294 & 0.609 & 0.350 & 0.194 & 0.203 & 0.314 & 0.076 \\
CV (\%) & 11.8 & 16.2 & 21.6 & 24.7 & 23.1 & 29.6 & 23.4 & 20.1 & 25.2 \\
\hline
\end{tabular}

Means followed by lowercase letters in column differ by Tukey's test $(\mathrm{P}<0.05)$.

The addition of copaiba or sucupira oils did not promote alterations in the intestinal epithelium possibly due to the absence of health challenge, since the performance enhancing additives are more expressive in adverse conditions. The addition of performance enhancers in animal feeding is one of the tools used to maintain the intestinal integrity as they act by reducing pathogens that may compromise the proper functioning of the gastrointestinal tract.

Some studies suggest that the use of phytogenic additives in broiler diets may be beneficial to the intestinal epithelium, and the different results observed between the studies may be related to the bioactive compounds produced by the secondary metabolism of each plant (BONA et al., 2012; HASHEMIPOUR et al., 2013).

SILVA et al. (2010) reported higher villus height for the jejunum of broilers fed $0.4 \%$ of essential oil of rose pepper (Schinus terebinthifolius) compared to broilers treated without the performance enhancer at 21 days of age. This effect may have been due to the presence of phenolic compounds found in Schinus terebinthifolius, with anti-inflammatory and antimicrobial properties.

Both copaiba and sucupira oils have terpene compounds, mainly sesquiterpenes such as $\beta$-caryophyllene. 
According to BEZERRA et al. (2010), this compound has antimicrobial effect, but no beneficial effect was observed on the intestinal mucosa at the levels tested. It is important to consider that the composition and amount of bioactive compounds in products extracted from plants can be influenced by environmental factors related to plant development such as soil type and climate, extraction method and identification of the compounds (MARTÍNEZ et al. al., 2012). Then, it is difficult to standardize vegetable oils and extracts and, consequently, to compare the results found in the literature regarding this type of material. Considering the above, copaiba oil at the level tested $(2,000 \mathrm{mg} / \mathrm{kg}$ of feed $)$ can be added to broiler diets without compromising performance. The sucupira oil at the level tested (500 $\mathrm{mg} / \mathrm{kg}$ of feed) is not recommended for broilers from 1 to 21 and 1 to 33 days of age due to the negative effects observed on performance during these periods.

\section{REFERENCES}

AGUILAR, C.A.L.; LIMA, K.R.S.; MANNO, M.C.; TAVARES, F.B.; SOUZA, V.P.; FERNANDES NETO, D.L.F. Effect of copaíba essential oil on broiler chickens' performance. Acta Scientiarum. Animal Sciences, v.35, p.145-151, 2013.

AMAD, A.A.; MÄNNER, K.; WENDLER, K.R.; NEUMANN, K.; ZENTEK, J. Effects of a phytogenic feed additive on growth performance and ileal nutrient digestibility in broiler chickens. Poultry Science, v.90, p.2811-2816, 2011.
BARRETO, M.S.R.; MENTEN, J.F.M.; RACANICCI, A.M.C.; PEREIRA, P.W.Z.; RIZZO, P.V. Plant extracts used as growth promoters in broilers. Revista Brasileira de Ciência Avícola, v.10, p.109-115, 2008.

BEN-MAHDI, M.H.; DJELLOUT, B.; BOUZAGH-BELAZOUZ, T; YAHIAOUI, F.; BEM-MAHDI, N.R. Intérêt de l'huile essentielle de thym dans l'amélioration des performances zootechniques et sanitaires du poulet de chair. Livestock Research for Rural Development, v.22, n.6, p.112, 2010.

BEZERRA, B.M.O.; FREIRE, J.J.F.; LEITE, L.O.; OLIVEIRA, M.L.M.; GUEDES, R.F.M.; PINHEIRO, D.C.S.N. Efeito anti-inflamatório tópico dos óleos de sucupira (Pterodon sp.) e copaíba (Copaifera sp.). In: 62 ${ }^{\mathrm{a}} \mathrm{REUNIÃO}$ ANUAL DA SBPC, 62., 2010, Natal. Anais... Natal: SBPC, 2010.

BONA, T.D.M.M.; PICKLER, L.; MIGLINO, L.B.; KURITZA, L.N.; VASCONCELOS, S.P.; SANTIN, E. Óleo essencial de orégano, alecrim, canela e extrato de pimenta no controle de Salmonella, Eimeria e Clostridium em frangos de corte. Pesquisa Veterinária Brasileira, v.32, p.411-418, 2012.

BURT, S. Essential oils: their antibacterial properties and potential applications in foods - a review.

International Journal of Food Microbiology, v.94, n.3, p.223-53, 2004.

DUTRA, R.C.; BRAGA, F.G.; COIMBRA, E.S.; SILVA, A.D.; BARBOSA, N.R. Atividades antimicrobiana e leishmanicida das sementes de Pterodon emarginatus Vogel. Revista Brasileira de Farmacognosia, v.19, p.429-435, 2009. 
DUTRA, R.C.; SILVA, P.S.; PITTELLA, F.; VICCINI, L.F.; LEITE, M.N.; RAPOSO, N.R.B. Caracterização fitoquímica e citogenética das sementes de Pterodon emarginatus Vogel.

Revista Técnico-Científica, v.3, n.1, p.99-109, 2012.

El BOUSHY, A.R.; KENNEDY, D.A. Flavoring agents improve feed acceptability. Poultry-Misset International, v.7, p.32-33, 1987.

FREITAS, E.R.; BORGES, A.S.; TREVISAN, M.T.; WATANABE, P.H.; CUNHA, A.L.; PEREIRA, A.L.F.; ABREU, V.K.;

NASCIMENTO, G.A.J. Extratos etanólicos da manga como antioxidantes para frangos de corte. Pesquisa

Agropecuária Brasileira, v.47, n.8, p.1025-1030, 2012.

FUKAYAMA, E.H.; BERTECHINI, A.G.; GERALDO, A.; KATO. R.K.; MURGAS, L.D.S. Extrato de orégano como aditivo em rações para frangos de corte. Revista Brasileira de Zootecnia, v.34, p.2316-2326, 2005.

HASHEMIPOUR, H.; KERMANSHAHI, H.; GOLIAN, A.; RAJI, A.; VAN KRIMPEN, M.M. Efeito do timol + carvacrol por nextenhance $150{ }^{\circledR}$ em intestinal desenvolvimento de frangos de corte alimentados cmc contendo diet. Iranian Journal of Animal Science Aplicada, v.3, p.567-576, 2013.

HASHEMI, S.R.; DAVOODI, H. Herbal plants and their derivatives as growth and health promoters in animal nutrition. Veterinary Research Communications, v.35, p.169-180, 2011.
KOIYAMA, N.T.G.; ROSA, A.P.; BOEMO, L.S.; PADILHA, M.T.S; SCHER A.; BRANCO T.; FORGIARINI, J. Performance Assessment of Broiler Chickens Supplemented with Copaiba Oil-Resin. Journal of Animal Production Advances, v.3, p.311-317, 2013.

KUZMUK, K.N.; SWANSON, K.S.; TAPPENDEN, K.A.; SCHOOK, L.B.; FAHEY, G.C. Diet and age affect intestinal morphology and large bowel fermentative end-product concentrations in senior and young adult dogs. The Journal of Nutrition, v.135, p.19401945, 2005.

LEANDRO, L.M.; VARGAS, F.S.; BARBOSA, P.C.S.; NEVES, J.K.O.; SILVA, J.A.; VEIGA-JUNIOR, V.F. Chemistry and biological activities of terpenoids from Copaiba (Copaifera spp.) oleo resins. Molecules, v.17, n.4, p.3866-3889, 2012.

LUNA, L.G. Manual of the histologic staining methods of the armed forces institute of pathology. $3^{\text {th }}$ ed. New York: Mc Graw Hill, 1968. 258p.

MARTÍNEZ, R.; TORRES, P.; MENESES, M.A.; FIGUEROA, J.G.; PÉREZ-ÁLVAREZ, J.A.; VIUDAMARTOS, M. Chemical, technological and in vitro antioxidant properties of mango, guava, pineapple and passion fruit dietary fibre concentrate. Food Chemistry, v.135, n.3, p.1520-1526, 2012.

MENDONÇA, D.E.; ONOFRE, S.B. Atividade antimicrobiana do óleo-resina produzido pela copaíba - Copaifera multijuga Hayne (Leguminosae).

Revista Brasileira de Farmacognosia, v.19, n.2, p.577-581, 2009. 
MONTES, L.V.; BROSEGHINI, L.P.; ANDREATTA, F.S.; SANT'ANNA, E.S.; NEVES, V.M.; SILVA, A.G.

Evidências para o uso do óleo-resina de copaíba na cicatrização de ferida - uma revisão sistemática. Natureza online [online], v.7, p.61-67, 2009.

PIERI, F.A.; SILVA, V.O.; SOUZA, C.F.; COSTA, J.C.M.; SANTOS, L.F.; MOREIRA, M.A.S. Antimicrobial profile screening of two oils of Copaifera genus. Arquivo Brasileiro de Medicina Veterinária e Zootecnia, v.64, n.1, p.241-244, 2012.

ROSTAGNO, H.S.; ALBINO, L.F.T.;

DONZELE, J.L; GOMES, P.C.;

OLIVEIRA, R.F.; LOPES, D.C.;

FERREIRA, A.S.; BARRETO, S.L.T.

Tabelas brasileiras para aves $\mathrm{e}$ suínos: composição de alimentos e exigências nutricionais. 3.ed. Viçosa, UFV, 2011, 252p.

SAS INSTITUTE. SAS/STAT: user's Guide. Version 9.2. Cary, 2009. 7869p.

SANTOS, U.; RAMOS, C.O.;

SANCHES, N.M.; SOUSA, F.F.

Propriedade antibacteriana dos frutos de Sucupira-Branca (Pterodon pubescens).

Revista Eletrônica de Biologia,

[online], v.3, p.77-88, 2010.

SILVA, M.A.; PESSOTTI, B.M.S.;

ZANINI, S.F.; COLNAGO, G.L.;

NUNES, L.C.; RODRIGUES, M.R.A.;

FERREIRA, L. Óleo de aroeira-

vermelha sobre o desempenho e a morfometria intestinal de frangos de corte. Ciência Rural, v.40, p.21512156, 2010.
UTIYAMA, C.E.; OETTING, L.L.; GIANI, P.A.; RUIZ, U.S.; MIYADA, S. Efeitos de antimicrobianos, prebióticos, probióticos e extratos vegetais sobre a microbiota intestinal, a frequência de diarréia e o desempenho de leitões recém-desmamados. Revista Brasileira de Zootecnia, v.35, p.2359-2367, 2006.

WINDISCH, W.M.; SCHEDLE, K.; PLITZNER, C.; KROISMAYR, A. Use of phytogenic products as feed additives for swine and poultry. Journal of

Animal Science, v.86, p.140-148, 2008.

Receipt date: 06/12/2017

Approval date: 06/03/2018 